\title{
Burden on relatives of people with psychic disorder: levels and associated factors
}

\section{Sobrecarga de familiares de pessoas com transtorno psíquico: níveis e fatores associados}

\author{
Viviane Porto Tabeleãoํㅗ Elaine Tomasi², Luciana de Ávila Quevedo ${ }^{1}$ \\ 1 Postgraduate Program in Health and Behaviour, Universidade Católica de Pelotas (UCPel), Pelotas, RS, Brazil. \\ 2 Department of Social Medicine, Universidade Federal de Pelotas (UFPel), RS, Brazil.
}

Received: 5/21/2013 - Accepted: 4/15/2014

DOI: 10.1590/0101-60830000000012

\begin{abstract}
Background: Studies have shown that overburden with care of psychotic patients is associated with a significant reduction of quality of life and causes harm to the caregiver's health. Objective: In order to compare factors associated with levels of burden of caregivers with the psychopathology of the patient, we conducted a cross-sectional study with 435 primary caregivers of patients of Centers for Psychosocial Care (CAPS) from Pelotas, RS. Methods: The patients were identified through medical records and their caregivers were interviewed in their homes. To evaluate the burden we used Zarit Burden Interview (ZBI). Results: Caregivers of dependent users of alcohol and drugs had the highest average of burden, 52.2 points (sd $=20.4$ ), followed by the caregivers of patients with suicide risk, 48.5 points $(\mathrm{sd}=0.7)$. In adjusted analysis, women had $8.2(95 \% \mathrm{CI}: 4.6,11.8)$ points higher on average than men in ZBI scale. Caregivers with less education had 1.6 (95\% CI: -3.1, -1.0) points lower on average of burden compared to those with higher educational level. Caregivers with some health problem had 6.7 (95\% CI: 3.3, 10.0) points higher in the middle of the ZBI when compared to those without disease. Discussion: Several factors overload clearly indicate the need to develop interventions such as psychoeducation which may give some support to the family responsible for care.
\end{abstract}

Tabeleão VP, et al. / Rev Psiq Clín. 2014;41(3):63-6

Keywords: Caregivers of psychiatric patients, burden, Zarit Burden Interview.

\section{Resumo}

Contexto: Estudos têm mostrado que a sobrecarga gerada no cuidado de pacientes psicóticos está associada com uma redução importante na qualidade de vida, trazendo danos à saúde do cuidador. Objetivo: Com objetivo de verificar fatores associados e comparar níveis de sobrecarga de cuidadores com a psicopatologia do paciente, foi realizado um estudo transversal com 435 cuidadores principais de usuários de Centros de Atenção Psicossocial (CAPS) da cidade de Pelotas, RS. Métodos: Os usuários foram identificados por meio de prontuários e seus familiares foram entrevistados posteriormente em suas residências. Para avaliar a sobrecarga, foi utilizada a Zarit Burden Interview (ZBI). Resultados: Cuidadores de usuários dependentes de álcool e drogas apresentaram as médias mais altas de sobrecarga, 52,2 pontos ( $\mathrm{dp}=20,4)$, seguidos dos cuidadores com risco de suicídio, 48,5 pontos $(\mathrm{dp}=0,7)$. Na análise ajustada, mulheres tiveram 8,2 (IC 95\%: 4,6; 11,8) pontos a mais na média do ZBI do que os homens. Cuidadores com menor escolaridade apresentaram 1,6 (IC 95\%: -3,1, -1,0) pontos a menos na média de sobrecarga comparados aos com maior grau de instrução. Cuidadores com algum problema de saúde tiveram 6,7 (IC 95\%: 3,3, 10,0) pontos a mais na média do ZBI comparado àqueles sem nenhuma doença. Conclusões: Vários fatores de sobrecarga indicam claramente a necessidade de se desenvolverem intervenções, como a psicoeducação, que possam dar algum tipo de apoio ao familiar responsável pelo cuidado.

Tabeleão VP, et al. / Rev Psiq Clín. 2014;41(3):63-6

Palavras-chave: Cuidadores de pacientes psiquiátricos, sobrecarga, Zarit Burden Interview.

\section{Introduction}

For many years, the psychiatric treatments were characterized by long periods of hospitalization, with the patient being away from family life. In the 80 's, it was necessary to rethink the mental health practices in Brazil. In the 90's, these practices became part of the public policies in Brazil, and in 2002, the Ministry of Health regulations established clear, effective and safe mechanisms to reduce the psychiatric beds, and consequently, psychiatric hospitals eventually replaced the older lunatic asylums. Thus, some health services were created, such as the Center for Psychosocial Health Care (CPHC), which is considered a reference for the treatment of people suffering from mental disorders, psychosis, severe neurosis and other conditions whose severity and/or persistence justify their treatment in a place that provides an intensive, community and individual care, and promotes life. Considering all these changes, the family became again the primary care for the patient, no longer a coadjuvant but the best ally in the rehabilitation process. In this new modality of treatment, all patients receive outpatient care and remain at home with their families, following a routine to ensure the basic needs of the patient, to coordinate daily activities, to administer medication, to deal with disruptive behaviors and episodes of crisis, to provide social support, and to bear the costs. This situation not only generated a great impact on daily basis, but also on the social and professional life of the family caregiver ${ }^{1-3}$. While it provides a good family environment, this change reveals lack of preparation of those who play the role of caregivers and contributes to increase their burden ${ }^{1}$.

Caregiver burden has been defined as a set of physical, emotional, financial and social problems, which directly affect the management of patients and the quality of life of caregivers ${ }^{4}$. Primary caregiver is the person that is part of the patient's family life, takes responsibility for the patient's day to day care and comfort without receiving compensation ${ }^{5}$.

Considering that mental health is not focused only on patient care but also on caregivers, it is essential to identify factors related to burden. Studies have shown that the burden resulting from taking care of psychotic patients is associated with a significant reduction in quality of life, which may affect the health of caregivers ${ }^{5,6}$. In addition

Address correspondence to: Viviane Porto Tabeleão. Universidade Católica de Pelotas. Programa de Pós-Graduação em Saúde e Comportamento. Rua Gonçalves Chaves, 373, sala 411C - 96015-560

- Pelotas, RS, Brazil. Phones: +55 (53) 2128 8404/+55 (53) 8115-7229. E-mail: vivianetabelea0@ig.com.br 
to poor quality of life, the caregivers of individuals with an affective disorder also experience problems related to physical health, social activities and feelings of nervousness, depression and tiredness ${ }^{7}$. For the family caregivers of drug addicts, reduced quality of life is known to contribute to the emergence of depressive symptoms, especially in cases where the spouses are the caregivers8.

In 2006, a study on psychosocial care carried out in the city of Pelotas, which included a characterization of caregivers of CPHC users, drew attention to the high level of burden experienced by these individuals .

Despite the growing interest in health and well-being of caregivers of patients with mental disorders, there is a scarcity of studies on the factors associated with burden and its relationship with the patient's psychopathology. The objective of this study was to assess the associated factors and to compare the burden level in caregivers with the psychopathology of CPHC users in the city of Pelotas, Brazil.

\section{Method}

This was a cross-sectional population-based study carried out in the city of Pelotas, Rio Grande do Sul, in 2011. The district has seven health units that provide assistance to approximately 1,000 primary caregivers suffering from mental disorders. The primary caregiver of each user was identified by trained academic students from the Psychology course at the Universidade Católica de Pelotas using the CPHC medical records. The caregiver answered a structured questionnaire, which was used to obtain socio-demographic information: gender (male/female), age categorized by quartile (40 years/41-54/55-63/64 years or more), education (Elementary/ Complete Elementary/Complete Middle School/Complete High School/Complete Higher Education), living with a partner (yes/no) - data on the user's contact with CPHCs and daily care - living with a caregiver (yes/no), any other relative with "bad nerves" (yes/no), any nervous condition (yes/no), any other health problem (yes/no), user's pathology (mood disorders, anxiety disorders, schizophrenia, epilepsy, nervous condition, risk of suicide, drug/alcohol) - including a specific evaluation of burden. All caregivers who were unable to understand the interview and had no daily contact with the CPHC user were excluded from the study.

The family members were asked about the pathology of the patient. Some of them were not able to give a diagnosis and described the patient's condition as "bad nerves". Consequently, we felt the need to create this additional category.

The primary caregiver burden was assessed using the Zarit Burden Interview Scale (ZBI) developed by Zarit \& Zarit, which was translated from its English original version by Scazufca ${ }^{10}$. This instrument was developed by Zarit \& Zarit. The scale assesses the burden in informal caregivers of individuals with mental or physical illnesses and measures the impact of care activities on the social, physical and emotional well-being and economic status of the caregiver. The responses are rated on a Likert scale with scores ranging from 22-110. Cut-off points were used to diagnose burden: absence of burden, moderate to severe burden.

Burden (ZBI) was analyzed by comparing the means using the Student's $t$ test and ANOVA. Variables with $\mathrm{p}<0.20$ were adjusted for linear regression analysis. The statistical analysis was performed using the SPSS version 13.0 for Windows (SPSS Inc., Chicago IL, USA).

The family members signed a written informed consent and had the confidentiality of personal information protected. The right of refusal to participate was fully guaranteed. The research was approved by the Research Ethics Committee of the Universidade Católica de Pelotas (Case N. 2010/33) according to resolution 196/96 of the National Health Council.

\section{Results}

A total of 911 users were identified in the CPHC records. Of these, 478 (52.4\%) refused to participate or were not found. This high percentage of losses occurred because 329 (68.8\%) users had not updated their addresses in CPHC files, and therefore, could not be not found; 12 (2.5\%) died before receiving the visit; $62(12.9 \%)$ had no responsible caregiver; 28 (5.8\%) did not attend the CPHC; 30 (6.2\%) refused to participate and 17 (3.5\%) did not live in the urban area of Pelotas. The final sample consisted of 435 caregivers.

Regarding the characteristics of the sample, the majority of caregivers (74\%) were female and $41.2 \%$ had completed elementary school. Sixty-five percent of caregivers lived with a partner, $82.3 \%$ lived with a CPHC user and $41.7 \%$ had another family member with a nervous condition. For the caregiver's health, $24.1 \%$ reported having "bad nerves" and $53.2 \%$ any other health problem (Table 1 ). The sample characteristics also included a family relationship, a relationship with relatives or an emotional bond with the user and found that primary caregivers were mostly mothers $(35.5 \%)$ of patients with psychological distress, spouses $(29.3 \%)$, children (15.4\%) and any other relative (19.8\%).

Figure 1 shows the items that appeared most frequently in the burden range, where $34.6 \%$ of respondents answered that they felt that the user depended on them, and almost $30 \%$ responded that they feared for the future of the user. It was also observed that $23.8 \%$ of caregivers felt that the user wished to be taken care by them as if they were the only persons he/she could depend on (Figure 1).

In the unadjusted analysis, the means of the scale were significantly higher for women $(\mathrm{p}<0.001)$, in caregivers with complete elementary school $(p=0.006)$, in caregivers of some other dependent individual with "bad nerves" ( $\mathrm{p}=0.043$ ), in respondents with a nervous condition $(\mathrm{p}=0.030)$, or with any other health problem $(\mathrm{p}=0.001)$ (Table 1$)$.

Table 2 shows the levels of burden related to the user's psychopathology. Caregivers of dependent users of alcohol and drugs had the highest mean burden score, $52.2(\mathrm{SD}=20.4)$, followed by caregivers at risk of suicide with a mean of $48.5(\mathrm{SD}=0.7)$. 'Having caregivers of CPHC users with mood disorder', had the lowest mean of 39.0 $(\mathrm{SD}=13.9)$ (Table 2).

After adjusting for confounding factors, the following variables remained associated with the outcome: gender $(p<0.001)$, education $(\mathrm{p}=0.050)$ and having other health problems $(\mathrm{p}<0.001)$. The mean scores on the ZBI for women were 8.2 higher (95\% CI: 4.6, 11.8) compared to men. The mean burden scores for caregivers with lower education was 1.6 (95\% CI: -3.1, -1.0) lower compared to the scores of those with higher education levels. 'With any other health problem', increased the mean scores on the ZBI to 6.7 (95\% CI: 3.3, 10.0) (Table 3).

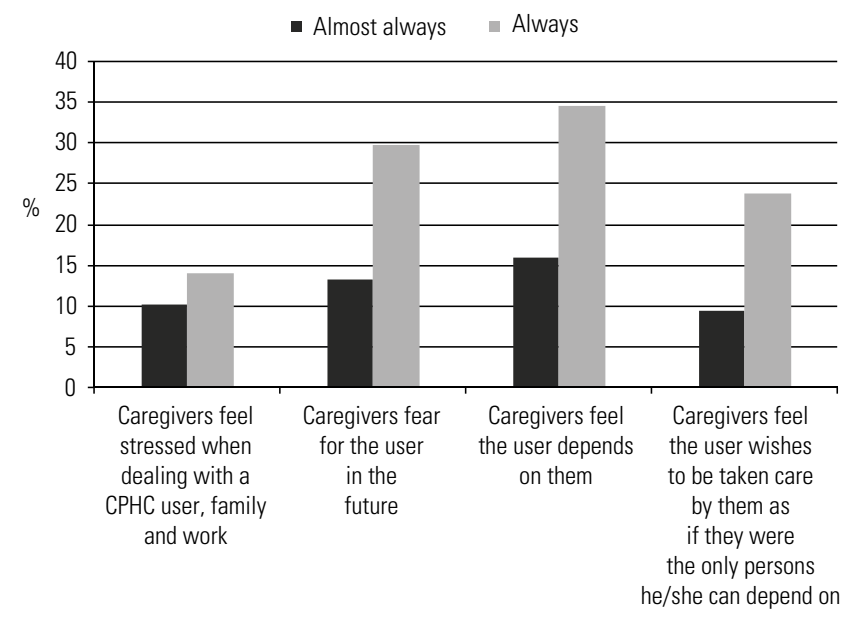

Figure 1. Most prevalent ZBI scale items (\%). 
Table 1. Distribution of the caregiver's characteristics and mean burden scores (ZBI)

\begin{tabular}{|c|c|c|c|c|}
\hline Variable & $\mathrm{N}$ & $\%$ & $\begin{array}{l}\text { Mean ZBI } \\
\text { (SD) }\end{array}$ & $\mathrm{p}$-value \\
\hline $\begin{array}{l}\text { Gender } \\
\text { Male } \\
\text { Female }\end{array}$ & $\begin{array}{l}112 \\
323\end{array}$ & $\begin{array}{l}25.7 \\
74.3\end{array}$ & $\begin{array}{l}37.7(13.5) \\
45.9(17.8)\end{array}$ & $<0.001$ \\
\hline $\begin{array}{l}\text { Age } \\
40 \text { years } \\
41-54 \\
55-63 \\
64 \text { years or older }\end{array}$ & $\begin{array}{l}111 \\
116 \\
100 \\
108\end{array}$ & $\begin{array}{l}25.5 \\
26.7 \\
23.0 \\
24.8\end{array}$ & $\begin{array}{l}39.8(14.5) \\
47.2(18.8) \\
45.1(15.7) \\
43.2(18.5)\end{array}$ & 0.264 \\
\hline $\begin{array}{l}\text { Education } \\
\text { Incomplete elementary } \\
\text { Elementary } \\
\text { Middle school } \\
\text { High school } \\
\text { Higher education }\end{array}$ & $\begin{array}{c}63 \\
160 \\
79 \\
77 \\
9\end{array}$ & $\begin{array}{c}16.2 \\
41.2 \\
20.4 \\
19.8 \\
2.3 \\
\end{array}$ & $\begin{array}{l}45.8(17.4) \\
43.9(17.2) \\
44.4(16.0) \\
38.6(15.0) \\
35.9(16.2)\end{array}$ & 0.006 \\
\hline $\begin{array}{l}\text { Living with a partner } \\
\text { No } \\
\text { Yes }\end{array}$ & $\begin{array}{l}151 \\
280\end{array}$ & $\begin{array}{l}35.0 \\
65.0\end{array}$ & $\begin{array}{l}43.9(17.1) \\
43.8(17.3)\end{array}$ & 0.941 \\
\hline $\begin{array}{l}\text { The user lives with a } \\
\text { caregiver } \\
\text { No } \\
\text { Yes }\end{array}$ & $\begin{array}{c}77 \\
358\end{array}$ & $\begin{array}{l}17.7 \\
82.3\end{array}$ & $\begin{array}{l}46.9(19.2) \\
43.2(16.7)\end{array}$ & $\begin{array}{l}0.084 \\
0.043\end{array}$ \\
\hline $\begin{array}{l}\text { Any family member with any } \\
\text { other nervous condition } \\
\text { No } \\
\text { Yes }\end{array}$ & $\begin{array}{l}279 \\
141\end{array}$ & $\begin{array}{l}58.3 \\
41.7\end{array}$ & $\begin{array}{l}42.9(16.7) \\
46.6(17.9)\end{array}$ & \\
\hline $\begin{array}{l}\text { The interviewee suffers from } \\
\text { "bad nerves" } \\
\text { No } \\
\text { Yes }\end{array}$ & $\begin{array}{l}328 \\
104\end{array}$ & $\begin{array}{l}75.9 \\
24.1\end{array}$ & $\begin{array}{l}42.9(16.2) \\
47.1(19.6)\end{array}$ & 0.030 \\
\hline $\begin{array}{l}\text { Any other health problem } \\
\text { No } \\
\text { Yes }\end{array}$ & $\begin{array}{l}185 \\
210\end{array}$ & $\begin{array}{l}46.8 \\
53.2\end{array}$ & $\begin{array}{l}44.1(17.0) \\
52.9(17.6)\end{array}$ & 0.001 \\
\hline Total & 435 & & $43.8(17.2)$ & \\
\hline
\end{tabular}

Table 2. Psychopathologies of CPHC users and mean burden scores (ZBI)

\begin{tabular}{|l|c|c|c|c|}
\hline & N & $\%$ & $\begin{array}{c}\text { Mean ZBI } \\
\text { (SD) }\end{array}$ & p-value \\
\hline $\begin{array}{l}\text { Psychopathologies of } \\
\text { CPHC users }\end{array}$ & & & & $<0.001$ \\
\hline Alcohol and drugs & 92 & 22.7 & $52.2(20.4)$ & \\
\hline Risk of suicide & 2 & 0.5 & $48.5(0.7)$ & \\
\hline Nerves & 49 & 12.1 & $47.4(17.4)$ & \\
\hline Epilepsy & 35 & 8.6 & $43.5(15.9)$ & \\
\hline Schizophrenia & 76 & 18.7 & $42.8(14.9)$ & \\
\hline Anxiety & 8 & 2.0 & $41.4(18.7)$ & \\
\hline Mood disorder & 144 & 35.4 & $39.0(13.9)$ & \\
\hline Total & 406 & 100 & $44.19(17.1)$ & \\
\hline
\end{tabular}

\section{Discussion}

All responsibility attributed to primary caregivers, combined with their lack of preparation to ensure some basic needs, such as proper use of medication, dealing with episodes of crisis of a mentally ill patient receiving treatment in outpatient, and remaining at home with their family members, are enormous tasks and caregivers may become overwhelmed by the demands associated with these roles that often come with physical and psychological problems. As family caregivers become a great ally in the treatment of a psychiatric patient, they should also be included in a treatment program and receive the same medical care services.

The results of this study showed significant differences between the caregiver burden levels of CHPC users regarding their psychopathologies. The burden levels were higher in those families caring for patients using drugs/alcohol, at risk of suicide, and with a nervous condition.

Regarding the burden of caregivers of patients addicted to alcohol and drugs, these findings may be associated with the high prevalence of other psychiatric disorders caused by substance abuse. Some users of alcohol and drugs are usually involved in an extremely stressful routine that includes running away from home, stealing family objects, being arrested for possession of illicit drugs or even drug trafficking, fighting in the streets, and compulsory hospitalization. It is known that many psychiatric illnesses are related to substance abuse, which is considered an external condition, consensually acquired by the individual. Studies carried out with relatives of drug users showed that caregivers are at elevated risk for developing mental health disorders, with greater frequency of physical attacks, death of family members and police involvement in domestic violence cases ${ }^{8-11}$.

The high mean scores for caregiver burden of users at risk of suicide were even evident with the small number of patients analyzed in this study. Suicide attempts and suicides are ranked among the most tragic events of life, causing severe psychological distress among family members and friends of the victims. It is known that suicide is more frequent in subjects with previous attempts, which increases alertness and concern in the family ${ }^{12}$.

Higher mean scores for subjects classified by their caregivers as having "bad nerves" were also analyzed. In literature, the condition described as "Bad Nerves" seems to be related to an incidence of stress, a situation where some of the most chronic symptoms tend to be overwhelming and often make it very difficult for the individuals to function effectively in their life ${ }^{2}$. The fact that a nervous condition is linked to a more severe disorder combined with a lack of understanding about the disease or a concept that describes such crises could justify the findings of the present study. Caution should be taken in relation to this data, considering that the domain "bad nerves" was created according to the response of the caregivers, therefore, the actual pathology could be inserted into any other group of pathology, leading to biased results.

For the burden associated factors, it was found that women, individuals with lower education level and with some health problem had higher levels of burden. Similar results were reported in a study performed with different types of caregivers in two cities of Minas Gerais ${ }^{1}$.

The literature indicates women as primary caregivers $\mathbf{s}^{1,2,8,13,14}$. This estimate may be due to a break of an expected life cycle, which

Table 3. Raw and adjusted analysis of factors associated with caregiver burden of $\mathrm{CPHC}$ users

\begin{tabular}{|c|c|c|c|c|}
\hline Variable & $\beta$ (Cl 95\%) Raw & $\mathrm{p}$-value & $\beta$ (Cl 95\%) Adjusted & p-value \\
\hline Gender (female) & $8.2(4.6,11.8)$ & $<0.001$ & $8.2(4.6,11.8)$ & $<0.001$ \\
\hline Age & $0.8(0.6,2.3)$ & 0.264 & & \\
\hline Education $(\uparrow)$ & $-2.2(-3.8,-0.6)$ & 0.006 & $-1.6(-3.1,-1.0)$ & 0.050 \\
\hline Living with a partner & $-0.1(-3.5,3.3)$ & 0.941 & & \\
\hline The user lives with a caregiver & $-3.8(-8.1,0.5)$ & 0.084 & $-1.2(-5.7,3.1)$ & 0.571 \\
\hline A family member with any other nervous condition & $3.6(0.1,7.1)$ & 0.043 & $2.3(-1.3,5.8)$ & 0.215 \\
\hline "Bad nerves" & $4.2(0.4,8.0)$ & 0.030 & $1.4(-2.7,5.5)$ & 0.495 \\
\hline Any other health problem & $8.8(3.7,13.9)$ & 0.001 & $6.7(3.3,10.0)$ & $<0.001$ \\
\hline
\end{tabular}


assumes that adults are independent. However, in most cases, it is not true for patients with psychological distress, as they will probably need someone to take care of them ${ }^{13}$. In most cases, for cultural reasons, women (mother, wife or grandmother) assume the caregiver role. The findings of the present study are consistent with the literature and reflect the tradition of caring, delegating responsibility to the woman who provides care for a family member with a health conditions. The task of care is connected to other tasks, such as caring for grandchildren so that the parents can go to work, caring for a sick family member, plus cleaning and organizing the house ${ }^{2}$.

The association between burden and low education level of the caregiver may be due to difficulty in assimilating information and knowledge about the disease, which could be helpful when caring for someone. It is also suggested that individuals with low education level also have low purchasing power, which increases the daily concerns and directly contributes for the burden.

The present study showed that most caregivers who suffer from caregiver burden had other health problems, which is in agreement with the results found in Belo Horizonte, where the most overworked individuals were those who were undergoing some health treatment, among other factors 3 .

The study has some limitations. First, the high number of losses reported due to the lack of updated addresses of CHPC users, which eventually restricted the number of subjects analyzed in this study. Second, patients at risk of suicide and with co-occurring alcohol and other drug use disorders are also likely to have other psychopathology. However, it was not possible to identify a comorbid pathology, because the criteria used to classify the patient's disorder was reported by the family, and not through the diagnosis given by the CHPC.

Nevertheless, the study provides information on factors that may be related to the increased burden of these caregivers, which enable us to construct action plans to reduce this burden. By involving the family in the treatment of mental patients, and giving support to face the difficulties in the relationship, the emotional burden of the family and the user is mitigated, and consequently, the level of interaction and empathy between them increases, bringing great benefits to treatment ${ }^{15}$. The results of this study aim to provide a better understanding of the concept and causes of burden of care, its impacts, and consequences on caregivers to help reduce adverse health outcomes.

Caregiver burden and related factors clearly indicate the need to develop effective intervention strategies, such as the inclusion of home medical consultations in public health programs for caregivers of individuals with mental disorders and psycho-educational intervention programs that can answer questions and give support to the family caregiver suffering from any psychological distress.

\section{References}

1. Albuquerque EPT, Cintra AMO, Bandeira M. Sobrecarga de familiares de pacientes psiquiátricos: comparação entre diferentes tipos de cuidadores. J Bras Psiquiatr. 2010;59(4):308-16.

2. Pegoraro RF, Caldana RHL. Sofrimento psíquico em familiares de usuários de um Centro de Atenção Psicossocial (CAPS). Comunicação Saúde Educação. 2008;12(25):295-307.

3. Barroso SM, Bandeira M, Nascimento E. Fatores preditores da sobrecarga subjetiva de familiares de pacientes psiquiátricos atendidos na rede pública de Belo Horizonte, Minas Gerais, Brasil. Cad Saúde Pública. 2009;25(9):1957-68.

4. Santos RL, Souza MFB, Brasil D, Dourado M. Intervenções de grupo para sobrecarga de cuidadores de pacientes com demência: uma revisão sistemática. Rev Psiq Clín. 2011;38(4):161-7.

5. Caqueo-Urízar AJ, Gutiérrez-Maldonado J, Miranda-Castillo C. Quality of life in caregivers of patients with schizophrenia: a literature review. Health Qual Life Outcomes. 2009;7:84.

6. Scazufca M. Abordagem familiar em esquizofrenia. Rev Bras Psiquiatr. 2000;22(1):50-2.

7. Zendjidjian X, Richieri R, Adida M, Limousin S, Gaubert N, Parola N, et al. Quality of life among caregivers of individuals with affective disorders J Affect Disord. 2012;136(3):660-5.

8. Marcon SR, RubiraI EA, EspinosaII MM, Barbosa DA. Qualidade de vida e sintomas depressivos entre cuidadores e dependentes de drogas. Rev Latino-Am. Enfermagem. 2012;20(1):167-74.

9. Tomasi E, Rodrigues J, Feijó G, Facchini LA, Piccini R, Thumé E, et al. Sobrecarga em familiares portadores de sofrimento psíquico que frequentam os Centros de Atenção Psicossocial. Saúde Debate. 2010;34(84):15967.

10. Scazufca M. Brasilian version of the Burden Interview scale for the assessment of burden of care in careers of people with mental illness. Rev Bras Psiquiatr. 2002;24(1):12-7.

11. Lima RAS, Amazonas MCLA, Motta JAG. Incidência de stress e fontes estressoras em esposas de portadores da síndrome de dependência do álcool. Estudos de Psicologia I Campinas I. 2007;24(4):431-9.

12. Rihmer Z. Can better recognition and treatment of depression reduce suicide rates? A brief review. Eur Psychiatry. 2001;16:406-9.

13. Barroso SM, Bandeira M, Nascimento E. Sobrecarga de familiares de pacientes psiquiátricos atendidos na rede pública. Rev Psiq Clín. 2007;34(6):270-7.

14. Hou SY, Ke CL, Su YC, Lung FW, Huang CJ. Exploring the burden of the primary family caregivers of schizophrenia patients in Taiwan. Psychiatry Clin Neurosci. 2008;62(5):508-14.

15. Borba LO, Schwartz E, Kantorski LP. A sobrecarga da família que convive com a realidade do transtorno mental. Acta Paul Enferm. 2008;21(4):588-94. 